\title{
Pink snow mold in winter cereal crops in Belarus and in the South of Russia
}

\author{
Alexander Zhukovskiy ${ }^{1}$, Natalia Krupenko $^{1}$, Yana Yakhnik $^{2}$, Olga Tarancheva $^{2}$, and Galina \\ Volkova $^{21}$ \\ ${ }^{1}$ Institute of Plant Protection, 2 Mira st., Minsk region, 223011, Belarus \\ ${ }^{2}$ All-Russian Research Institute of Biological Plant Protection, p/o 39, Krasnodar, 350039, Russia
}

\begin{abstract}
The article presents an analysis of the distribution and development of pink snow mold (pathogen Microdochium nivale (Fr.) Samuels \& I.C. Hallett) on winter cereal crops in the Republic of Belarus and in the South of Russia. Pink snow mold is currently one of the most harmful diseases of winter cereal crops, as it can cause damage not only to various parts of the plants, but also lead to their complete death. The intensity of the disease development mainly depends on weather conditions in the autumn-spring period, namely, on the duration of snow cover, its height and the rate of melting in spring. We determined the dependence of the disease development progress on agroclimatic conditions. There is a description of weather conditions in combination with a gradation of the disease development level in the Republic of Belarus and in Krasnodar Krai (southern Russia) during the epiphytotic and depressive years of the pink snow mold development. The article provides a retrospective analysis of the crops infected with pink snow mold and the treated cereal crops in southern Russia in 2011-2019.
\end{abstract}

\section{Introduction}

Snow mold - Microdochium nivale (Fr.) Samuels \& I.C. Hallett (telemorphic stage Monographella nivale (Schaffnit) E. Muller) is the pathogen of many complexes of destructive diseases of cereals and forage crops. The phytopathogen can cause not only damage to plants and decrease seed germination, but also lead to their complete death [1, 2]. The pathogen has a wide phylogenetic specialization. The reason for this was the high biological plasticity of $M$. nivale and the lack of organotropic confinement $[3,4]$. The disease is widespread in Sweden, Germany, Poland, China, Austria, Central Europe, USA, Canada and Scandinavia [5]. The surveys in Belarus indicate the widespread prevalence of snow mold in winter cereal crops [6]. In Russia, the fungus is found in all areas of winter cereal crops cultivation: in the European part, in the North Caucasus, in Kabardino-

Corresponding author: galvol.bpp@yandex.ru 
Balkaria, the Central Federal District, the Republic of Bashkortostan, Chuvashia, Mari El, in the Ural Federal District and many other areas [7, 8].

$M$. nivale pathogen has an unusual ability to grow at temperatures approaching freezing point or even slightly below it $[6.7,9]$. M. nivale mycelium can grow and spread at low temperatures due to the release of antifreeze proteins up to $-5^{\circ} \mathrm{C}$. In 2015 the researcher M Hiilovaara-Teiyo et al. [10] wrote about this ability of the pathogen to form and secrete antifreeze proteins that inhibit ice growth during freezing, which at the same time ensure pathogen growth stability. Freezing increases the virulence of the pathogen, while taking into account the fact of maintaining the integrity of the coleoptile seedlings of the host plant [9].

$M$. nivale fungus is one of the most harmful winter cereal crops diseases. Parasitizing on living wheat tissues in autumn, winter and spring, the fungus significantly weakens plants, leading to a decrease in the main productive qualities of wheat, which affects yield $[11,12]$. Pink snow mold is currently one of the most harmful diseases of winter cereal crops, as it can cause damage not only to various parts of the plant, but also lead to their complete death [13]. The intensity of the disease development mainly depends on weather conditions in the autumn-spring period, namely on the duration of snow cover, its height and the rate of melting in spring. Also, this process is influenced by agrotechnical techniques, such as rotation of crops that are not host plants of M. nivale, deep tillage, timely sowing $[8,14]$. The most effective way to control $M$. nivale is the use of the integrated plant protection system: the cultivation of winter-hardy and resistant varieties of winter cereal crops, the use of chemical and biological protection agents $[7,15,16]$. Knowing the areas of snow mold spreading, as well as isolation of the regions with a more intensive disease development is an important step in developing protective measures strategy.

Due to favorable climatic conditions for $M$. nivale pathogen in the Russian Federation, there is about 16-30\% yield loss caused by the infection [17]. The distribution and development of pink snow mold is determined by a complex of abiogenic factors, such as an increase in precipitation, an early temperature transition closer to $0{ }^{\circ} \mathrm{C}$ during the growing season, a long period of snow melting and snow cover.

Researcher Hoshino et al. (Finland) in 2013 determined the low-temperature adaptation of snow mold strains from an environmental and biochemical points of view and found that the pathogen can survive at $-40{ }^{\circ} \mathrm{C}$, and after stressful freezing conditions it can grow at sublethal temperatures. The complex of physiological mechanisms allowed the fungi to adapt to rather severe conditions [18], including polar regions as a habitat [19]. Snow mold was not found in the Republic of Yakutia, presumably due to the extreme conditions of low temperatures with the presence of a long snow cover [7]. These factors contribute to the active life of the pathogen and, accordingly, lead to the weakening and death of the affected host plant. A decrease in yield occurs due to a decrease in the number of productive stems and grains per ear. The intensity of the disease development can depend not only on the presence of infection in the soil and meteorological conditions, but also on a variety resistance to the disease. Therefore, the use of resistant varieties of winter crops is an important aspect, since the assortment of winter crops susceptible to the pathogen contributes to an increase in the phytopathogen population, not only exceeding the threshold of economic harmfulness, but also ensuring the long-term preservation of the increased infectious background of crops [20].

In the Republic of Belarus, the most harmful disease of winter cereal crops is pink snow mold, since epiphytoties happen 1-2 times every five years, and yield losses can reach more than $40 \%$ [14]. The problem of the pink snow mold spreading is also very important for the South of Russia, since the phytopathogen practically wasn't found until 1995, but since 2000 there has been a dynamics in the manifestation and development of snow mold [21]. 
Relative independence on the snow cover also contributes to wide spreading of the phytopathogen [7, 22]. M. nivale is of particular importance for the foothills of Krasnodar Krai, where epiphytoties break out with a frequency of 3-5 years out of ten, and yield losses amount up to $10-20 \%[5,8]$.

The aim of the research was to monitor the prevalence and development of pink snow mold in winter cereal crops in Belarus and in southern Russia.

\section{Materials and methods}

Studies in the territory of the Republic of Belarus were carried out in winter cereal crops on the experimental field of the RUE "Institute of Plant Protection", at the State variety-testing stations and sites, as well as in farms [14]. In Krasnodar Krai (southern Russia), the analysis of the snow mold spreading was carried out using phytomonitoring data provided by the researchers of FSBSI ARRIBPP and the specialists from the FSBI Rosselkhoztsentr branches in 2011 - 2019 [23].

\section{Results and discussion}

The results of the monitoring of snow mold spreading and development in 2015-2020 indicate the dependence of the spread of the disease in the Republic of Belarus primarily on weather conditions. So, in 2015, 2017, 2018 and 2020, there was scarce pink snow mold spreading in spring, which is explained by the short-term duration of snow cover or its almost complete absence observed in 2019-2020 winter. Under the conditions of 2016, the maximum percentage of disease prevalence ranged from $14.4 \%$ (wheat) to $44.4 \%$ (triticale). At the same time, in some fields in the Vitebsk region, a high prevalence and development of the disease were noted. However, this was characteristic of crops located along the edges of forests, where snow cover melted slowly. For example, in the Vitebsk region, with $100 \%$ snow mold prevalence in winter wheat crops, the disease development reached $51.5 \%$, and the death of the plants caused by the disease $-18.0 \%$. In 2019 , a moderately epiphytotic nature of the disease was noted with a spread of $72.0 \%$ to $100 \%$. The maximum disease development was noted in the north of the country on winter wheat $(80.5 \%)$, winter triticale $(75.0 \%)$ and winter rye $(74.0 \%)$. The death of the plants under such conditions ranged from $20 \%$ in winter rye crops to $44.0 \%$ in winter wheat and triticale crops.

Agroclimatic analysis revealed the peculiarities of the influence of weather conditions on the spread of snow mold in Krasnodar Krai in 2011 - 2019 [23]. The general dynamics of the disease spread and development can be seen in Figure 1. The greatest pathogen prevalence was detected in 2011, 2012 and 2017. Unfavorable weather conditions caused a high level of pink snow mold spreading in 2011 due to the cold weather with precipitation in the early spring, and weakening of winter cereal crops during winter. In 2012, the damage to crops by snow mold was due to heavy snowfalls and long-lasting snow cover in the winter in the fields. The weather conditions of April 2017 contributed to the widespread manifestation and prevalence of the disease, but already in May there was an increase in air and soil temperature, there was no snow cover, which prevented the further development of the disease.

The maximum disease development was directly dependent on the disease spreading. So, in 2011, the pink snow mold disease spreading was $16.5 \%$, and the disease development was $3.7 \%$. In 2012, the spread of the pathogen increased to $18.2 \%$ and the disease development amounted up to $3.8 \%$. The highest phytopathogen prevalence was 
found in 2017 and amounted up to $33.6 \%$. The average disease development was at the level of $3.5 \%$. The maximum disease spreading (60\%) was recorded in the Ust-Labinsky district of Krasnodar Krai.

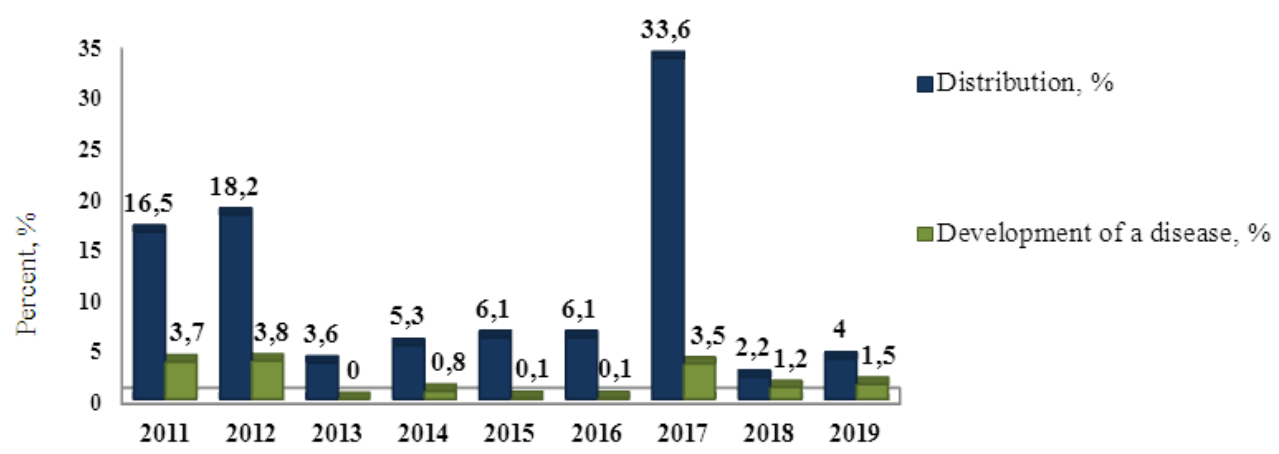

Fig.1. Spreading and development of Microdochium nivale in Krasnodar Krai in 2011 - 2019

The depressive development of pink snow mold was observed from 2013 to 2016, as well as from 2018 to 2019 . Disease prevalence ranged from $2.2 \%$ to $6.1 \%$, and the maximum disease development amounted up to $1.5 \%$. The high temperature regime in 2013 contributed to the early resumption of winter crops vegetation, which led to overgrowing of crops, therefore, the development of pink snow mold was observed at the edges of crops and in unaligned areas in the south-foothill and central regions of Krasnodar Krai. In 2014, temporary snow cover and frequent thaws were observed, which caused early spring damage to the stems, leaves and root system. In 2015, a low infectious background was noted, but the cool weather during the heading phase contributed to the further development of snow mold on the leaves and stems and led to spike damage, which provoked fusarium burn almost everywhere. In 2016, mild and warm winters with snow and thaws provoked early damage to the leaves, stems and root system by pink snow mold, and the cool weather in May stimulated the disease development up to the spike damage. In 2018 the spring weather was characterized by the absence of snow cover, as a result of which intense pink snow mold infection wasn't observed. The shortage of precipitation and the average temperature increased by $1-3{ }^{\circ} \mathrm{C}$ in April inhibited the development of the disease on the stems and leaves. The absence of continuous snow cover in winter did not contribute to the widespread disease prevalence. In 2019, a focal M. nivale infection of winter cereal crops was noted in the first decade of March, April was characterized by low frosts and a lack of precipitation, which affected the slowdown of the pathogen development. In 2020, the pink snow mold spreading in Krasnodar Krai, as well as in the Republic of Belarus, was rather scarce in the spring period, due to the lack of snow cover, warm winters and dry spring.

Agroclimatic conditions are one of the main factors determining the economic threshold of harmfulness (hereinafter ETH) of M. nivale pathogen. When the disease development rate is higher than ETH, it is advisable to use fungicidal treatments of crops. A retrospective analysis of the infected and treated areas of cereal crops in the Southern Federal District of Russia (Republic of Adygea, Republic of Crimea, Simferopol, Sevastopol, Rostov Region, Republic of Kalmykia, Astrakhan Region, Volgograd Region, Krasnodar Krai) is shown in Figure 2. 


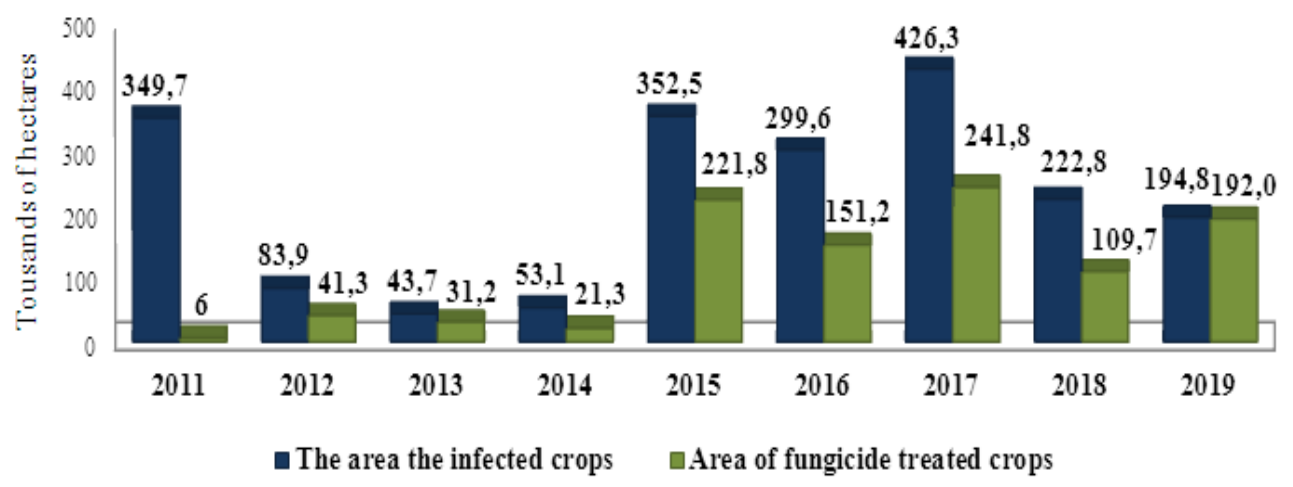

Fig.2. The cereal crops areas infected and treated with the protection products against M. nivale in southern Russia, 2011-2019

In 2011, due to adverse weather conditions in spring and the difficult wintering of winter cereal crops, the disease spread to 349.7 thousand ha, treatments were carried out on 6 thousand ha, which amounted up to $1.7 \%$ of the total infected area. In 2012, with the disease prevalence significant for southern Russia, ETH was the rationale for the use of pesticides in almost half of the infected crops - $49.3 \%$. 2013 was characterized by a low prevalence and development of the disease; treatments were carried out on most of the cultivated areas, accounting for $71.5 \%$ of the infected territories. In 2014, agroclimatic conditions favorably influenced the development and spread of M. nivale, a low level of pathogen infection was detected, treatments were carried out on $40.0 \%$ of the infected crops. A low level of pathogen spreading was noted in 2015 - 2016, however, the areas of the infected crops were quite extensive (352.54 thousand ha and 299.65 thousand ha, respectively), which justified the use of fungicidal treatments for $62.9 \%$ of $M$. nivale infected territory in 2015 and $50.5 \%$ of the infected crops in 2016. The epiphytotic spreading of M. nivale in southern Russia in 2017 was suspended by dry, clear weather in May, the area affected by the phytopathogen was the highest since 2011, treatments against M. nivale were also carried out in the largest volume - 241.8 thousand ha, amounting up to $56,7 \%$ of the infected crops. The agro-climatic conditions of 2018 contributed to the low level of $M$. Nivale spreading, however, the area of the affected crops was at a fairly high level - 222.85 thousand ha, treatment was carried out on $49.2 \%$ of the infected area. It is worth noting that in 2019 there was the highest level of treatments, since $98.6 \%$ of 194.8 thousand ha of the infected area were treated.

In Belarus, on the experimental field of the RUE "Institute of Plant Protection", a detailed analysis of the disease development, depending on the crop from the plots where the seeds were not treated with fungicides, was carried out. The obtained data indicate that during the years of the epiphytotic disease development this indicator reached its maximum values in winter wheat and winter triticale crops, as a result, plant death under such conditions reached $68.1 \%$ and $59.6 \%$, respectively, which proves a high harmfulness of snow mold ( Table 1). Despite the high rate of disease development, winter rye is more tolerant during epiphytotic years, and the death of plants did not exceed $7.4 \%$. In the years of moderate disease development plant death due to the damage was not significant and did not exceed $6.0 \%$ in winter triticale crops.

In general, over the past 11 years of the research, the epiphytotic development of snow mold on winter cereal crops in Belarus was noted four times (2010-2013, 2019). 
Table 1. Pink snow mold in winter cereal crops, RUE Institute of Plant Protection, Belarus

\begin{tabular}{|l|c|c|c|c|c|c|}
\hline \multirow{4}{*}{ Crop } & \multicolumn{6}{|c|}{ Characteristics of vegetation seasons } \\
\cline { 2 - 7 } & $\begin{array}{c}|c| \\
\text { epiphytotic } \\
\end{array}$ & $\begin{array}{c}\text { moderate }(2012) \\
\text { (2010, 2011, 2013, 2019) }\end{array}$ & \multicolumn{2}{c|}{$\begin{array}{c}\text { depressive } \\
(2014-2018,2020)\end{array}$} \\
\cline { 2 - 7 } & $\begin{array}{c}\text { development, } \\
\%\end{array}$ & $\begin{array}{c}\text { death, } \\
\%\end{array}$ & $\begin{array}{c}\text { development, } \\
\%\end{array}$ & $\begin{array}{c}\text { death, } \\
\%\end{array}$ & $\begin{array}{c}\text { development, } \\
\%\end{array}$ & $\begin{array}{c}\text { death, } \\
\%\end{array}$ \\
\hline wheat & $67.2-88.7$ & $19.3-68.1$ & 33.8 & 2.8 & $0.0-15,0$ & 0.0 \\
\hline triticale & $71.1-87.5$ & $42.1-59.6$ & 32.4 & 6.0 & $0.0-24.7$ & 0.0 \\
\hline rye & $54.8-61.6$ & $0.0-7.4$ & 25.1 & 0.0 & $15.7-25.0$ & 0.0 \\
\hline barley & 41.4 & 10.6 & 36.7 & 2.5 & $3.7-22.4$ & 0.0 \\
\hline
\end{tabular}

\section{Conclusions}

Agroclimatic analysis revealed a close relationship between weather conditions and $M$. nivale spreading and development in winter cereal crops. The conditions of overwintering, the resumption of vegetation on the host plant, as well as temperature and humidity level have a complex effect on the vital activity of the phytopathogen, which is consistent with the studies of several authors $[8,10,13,14]$. There is still an important problem of specifying the influence of various abiotic factors on the penetration of the fungus into the stem of winter cereal crops and the further spike damage with M. nivale. In Krasnodar Krai there is a lack of the studies aimed at a detailed analysis of the disease development depending on the breads of the first group, which confirms the need for further study of the interaction of the pathosystem «M. nivale - the host plant» in various agroclimatic zones.

The studies were supported by the BRFFR Grant No. B20R-272 and the RFBR Grant Bel_a No. 20-54-00026

\section{References}

1. J. Dempsey, I. Wilson, P. T. Spencer-Phillips, Plant Pathology, 6 (2020) https://scihub.im/10.1111/ppa.12846

2. R. Runsheng, J. Foulkes, S. Mayes, Field crops research, 191 (2016) https://scihub.im/10.1016/j.fcr.2016.03.011

3. K. Marzec-Schmidt, K. Hura, A. Plazek, Physiological and molecular Plant Pathology, 104 (2018) https://sci-hub.im/10.1016/j.pmpp.2018.08.006

4. J. Liang, G. Li, M. Zhao, Mycologia, 2 (2019) https://scihub.im/10.1080/00275514.2019.1569417

5. A. G. Shchukovskaya, O. B. Tkatchenko, A. A. Shesteperov, Russian Journal of Parasitology, 2 (2014) https://vniigis.elpub.ru/jour/article/view/228?locale=en_US

6. A.G. Zhukovsky, N.A. Krupenko, S.F. Buga et al., Plant Protection, 42 (2018) http://izr.by/doc/zr42.pdf\#page $=96$

7. O.B. Tkachenko, R. Imai, M. Yoshida, N. Matsumoto, In Plant and Microbe Adaptation to Cold in a Changing World, 1 (2013) https://link.springer.com/content/pdf/bfm\%3A978-1-4614-8253-6\%2F1.pdf

8. O.B. Tkachenko, A.V. Ovsyankina, A.G. Shchukovskaya, Sel'skokhozyaistvennaya biologiya, 1 (2015) https://cyberleninka.ru/article/n/snow-molds-history-of-the-study-andcontrol-review

9. I. Haigh, C. Martin, International Journal of Agronomy, 4 (2012) http://downloads.hindawi.com/journals/ija/2012/359017.pdf 6

10. A. Hannukkala, M. Griffith, Yu. X-M, K. Pihakaski-Maunsbach, Plant Physiology, $121(2011)$ 
http://www.plantphysiol.org/content/plantphysiol/early/2006/06/30/pp.106.081935.full.pdf? versioned=true

11. P. Matusinsky, L. L. Svobodova, I. Svacinova, European journal of Plant Pathology, 1 (2019) https://sci-hub.im/10.1007/s10658-019-01737-8

12. M. Dyda, I. Wasek, M. Tyrka, Physiologia plantarum, 4 (2019) https://scihub.im/10.1111/ppl.12760

13. R. Ren, X. Yang, R.V. Ray, Eur J Plant Pathol, 141 (2015) https://link.springer.com/content/pdf/10.1007/s10658-014-0541-3.pdf

14. Zhukovski, N.A. Krupenko, S.F. Buga, Plant Protection News, 4 (2019) http://plantprotect.ru/index.php/vizr/article/view/4827

15. C. Yang, C. Hamel, V. Vujanovic, Y. Gan, Ecology, 10 (2011) https://www.hindawi.com/journals/isrn/2011/130289/

16. T. Espevig, T. Pettersen, T. Aamlid, BIO Web Conf, 18 (2020) https://www.bioconferences.org/articles/bioconf/abs/2020/02/bioconf_vizr2020_00007/bioconf_vizr2020_0 0007.html

17.N. Matsumoto, Microbes Eviron., 24 (2009), Source: https://pdfs.semanticscholar.org/e79e/815c9f6edde7055380cc897f7d00af0953b8.pdf

18.T. Hoshino, N. Matsumoto, Karstenia, 53 (2013), Source: http://www.funga.fi/Karstenia/Karstenia 53-1-2_2013-6.pdf

19.M. Tojo, K.K. Newsham, Fungal Ecology, 5 (2012), Source: https://www.researchgate.net/publication/257693632 Snow moulds in polar environments

20. O. G. Mar'ina-Chermnyh, M. A. Evdokimova, Vestnik Ul'janov. gos. s/h. akad. 4 (2015), Source: http://agro-econom.vestnik.marsu.ru/uploads/files/articlesPdf/1206_ru.pdf

21. M.I.Zazimko, Protection argument, (2015), Source: https://betaren.ru/pressa/75/

22. E. Dubas, Acta Physiologiae Plantarum, 33 (2010), Source: https://www.researchgate.net/publication/236131451_Microdochium_nivale_Fr_Samuels Hallett Cytological analysis of the infection process in triticale Triticosecale Wittm

23.D.N. Govorov, A.V. Zhivykh et al., Russian agricultural center (2011-2019) https://rosselhoscenter.com/849-obzor-i-prognozy 